DEPARTMENT OF THE INTERIOR

UNITED STATES GEOLOGICAL SURVEY

\title{
GEOLOGIC MAP OF THE HUNTSVILLE QUADRANGLE, WEBER AND CACHE COUNTIES, UTAH
}

By Martin L. Sorensen and Max D. Crittenden, Jr.
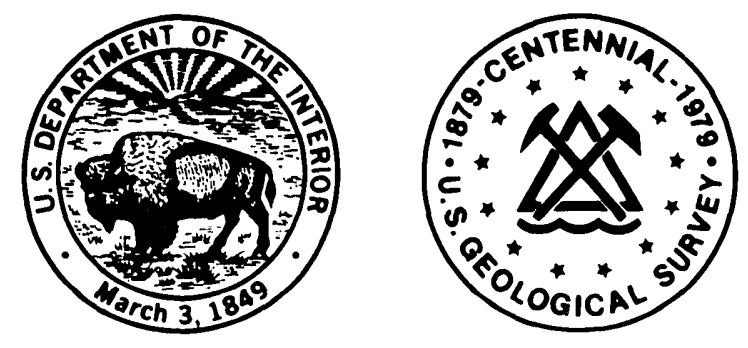


\section{GEOLOGIC MAP SYMBOLS \\ COMMONLY USED ON MAPS OF THE UNITED STATES GEOLOGICAL SURVEY \\ (Special sy mbols are shown in explanation)}

Contact-Dashed where approximately located; short dashed where inferred; dotted where concealed

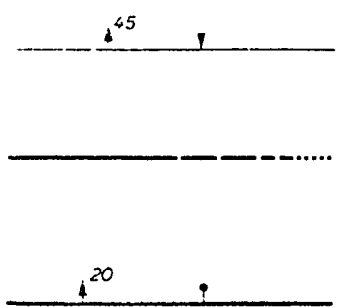

Contact-Showing dip; well exposed at triangle

Fault-Dashed where approximately located; short dashed where inferred; dotted where concealed

Fault, showing dip-Ball and bar on downthrown side

Normal fault-Hachured on downthrown side

Fault-Showing relative horizontal movement

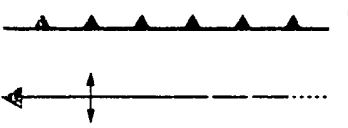

Thrust fault-Sawteeth on upper plate

Anticline-Showing direction of plunge dashed where approximately located; dotted where concealed

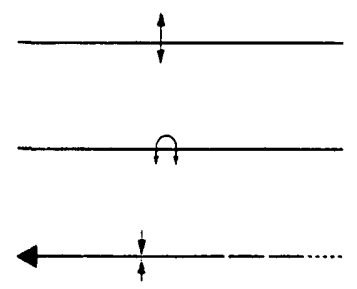

Asymmetric anticline-Short arrow indicates steeper limb

Overturned anticline--Showing direction of dip of limbs

Syncline-Showing direction of plunge; dashed where approximately located; dotted where concealed

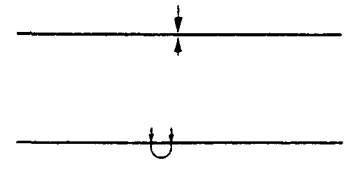

Asymmetric syncline-Short arrow indicates steeper limb

Overturned syncline--Showing direction of dip of limbs

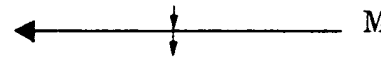

Monocline-Showing direction of plunge of axis

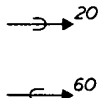

Minor anticline-Showing plunge of axis

Minor syncline-Showing plunge of axis
Strike and dip of beds-Ball indicates top of beds known from sedimentary structures

$\stackrel{70}{\perp}$ Inclined $\oplus$ Horizontal

+ Vertical $\underset{40}{40}$ Overturned

Strike and dip of foliation

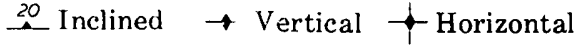

Strike and dip of cleavage

.5 Inclined $\longmapsto$ Vertical I Horizontal

Bearing and plunge of lineation

15 Inclined $\bullet$ Vertical $\longleftrightarrow$ Horizontal

Strike and dip of joints

40 Inclined $\rightarrow$ - Vertical $\rightarrow$ Horizontal

Note: Planar symbols (strike and dip of beds, foliation or schistosity, and cleavage) may be combined with linear symbols to record data observed at same locality by superimposed symbols at point of observation. Coexisting planar symbols are shown intersecting at point of observation.

Shafts

$\square$ Vertical $\square$ Inclined

Adit, tunnel, or slope

$\succ$ Accessible $>$ - Inaccessible

X Prospect

Quarry

父Active $\quad$ Abandoned

Gravel pit

$X$ Active $\quad \Varangle$ Abandoned

Oil wells

- Drilling $\phi$ Shut-in $\phi-\phi$ Dry hole,

Gas Show of gas abandoned

- Oil $\quad$ Show of oil 